University of Pennsylvania Carey Law School

Penn Carey Law: Legal Scholarship Repository

Faculty Scholarship at Penn Carey Law

9-2019

\title{
The American Pathology of Inequitable Access to Medical Care
}

\author{
Allison K. Hoffman \\ University of Pennsylvania Carey Law School \\ Mark A. Hall \\ Wake Forest University, School of Law
}

Follow this and additional works at: https://scholarship.law.upenn.edu/faculty_scholarship

Part of the Comparative and Foreign Law Commons, Constitutional Law Commons, Health Economics Commons, Health Law and Policy Commons, Health Policy Commons, Health Services Administration Commons, Law and Society Commons, Legislation Commons, Policy Design, Analysis, and Evaluation Commons, and the Public Law and Legal Theory Commons

\section{Repository Citation}

Hoffman, Allison K. and Hall, Mark A., "The American Pathology of Inequitable Access to Medical Care" (2019). Faculty Scholarship at Penn Carey Law. 2213.

https://scholarship.law.upenn.edu/faculty_scholarship/2213

This Book Chapter is brought to you for free and open access by Penn Carey Law: Legal Scholarship Repository. It has been accepted for inclusion in Faculty Scholarship at Penn Carey Law by an authorized administrator of Penn Carey Law: Legal Scholarship Repository. For more information, please contact PennlawIR@law.upenn.edu. 


\begin{abstract}
Allison K. Hoffman and Mark A. Hall
The American Pathology of Inequitable Access to Medical Care

For published version:

https://www.oxfordhandbooks.com/view/10.1093/oxfordhb/9780190846756.001.0001/oxford $\underline{\text { hb- } 9780190846756-e-55}$
\end{abstract}

\title{
I. Overview of Access to Health Care in the United States
}

What most defines access to health care in the United States may be its stark inequity. Daily headlines in top newspapers paint the highs and lows. Articles entitled: "We Mapped the Uninsured. You'll notice a Pattern: They tend to live in the South, and they tend to be poor"1 and op-eds with titles like "Do Poor People Have a Right to Health Care?" 2 and "What it's Like to Be Black and Pregnant when you Know How Dangerous That Can $\mathrm{Be}^{\prime \prime}{ }^{3}$ run side-by-side with headlines touting "The Operating Room of the Future," ${ }^{4}$ and advances in gene therapy that promise cures to everything form vision loss to cancer, accompanied by high six-figure price tags. ${ }^{5}$ Americans' claims that they have access to the best medical care in the world are correct. Equally true are the claims that the system is broken.

This chapter maps out the complex picture of access to medical care in the United States and reflects on how variable access illustrates, among other things, an American ambivalence about health solidarity. This Chapter first considers health care financing as one critical element that defines access to medical care and describes the multifaceted U.S. health care financing structure, predominated by public insurance programs for select populations and regulated private insurance for others. Second, this Chapter describes how access is equally shaped by legal requirements that create treatment obligations for doctors or hospitals, regardless of how someone pays for care. There is no constitutional right to health in the U.S., but various layers of statutory and common law have created some guarantees. That said, despite efforts to

${ }^{1}$ Quoctrung Bui \& Margot Sanger-Katz, We mapped the Uninsured. You'll Notice a Pattern, NY TIMES (Oct. 30, 2015).

2 The Editorial Board, Do Poor People Have a Right to Health Care? NY TIMES EdITORIAL (July 7, 2018).

${ }^{3}$ Dani McClain, What It's Like to Be Black and Pregnant When You Know How Dangerous That Can Be, The Nation (March 6, 2017). See also Linda Villarosa, Why America's Black Mothers and Babies Are in a Life-or-Death Crisis, NY Times (April 11, 2018).

${ }^{4}$ Laura Landro, The Operating Room of the Future, WALL STREET J. (May 28, 2018).

${ }^{5}$ Peter Loftus, Drug Firm Spark Therapeutics Will Charge \$850,000 for Vision-Loss Gene Therapy, WALL STREET J. (Jan 3, 2018). 
increase access over the past decades, the United States is still extraordinary, as compared to peer nations, on the unevenness of access to medical care among its population.

Even after the passage of the Patient Protection and Affordable Care Act in 2010 (ACA), nearly 10 percent of the total population remains uninsured and, in many cases, lacks access to basic medical care. ${ }^{6}$ Even many people with insurance struggle to pay the cost-sharing necessary to use medical care. And some cannot get access to doctors, whether insured or not. Despite legal obligations, providers still enjoy considerable autonomy over whom they care for and when. And most laws that create treatment obligations are silent about who will pay for that care, possibly leaving patients who receive lifesaving care with crippling medical debt.

Scholars attribute the perpetuation of this uneven picture to a range of factors: organized medicine and other interest groups' resistance to public insurance, broader ideological skepticism of government or of new taxes, path dependency and inertia. ${ }^{7}$ At its root, disparities in access draw from the fact that the notion of a right to health care does not have and never has had the same salience in the United States as in its peer nations. In turn, the existing system undermines health solidarity by reproducing a norm where access to health care is not universal. Even though U.S. laws have facilitated or guaranteed access to care for some people and in some circumstances, the absence of consensus on any coherent guiding principle is evident in the remaining gaps.

\section{Financing and Health Insurance as Point of Entry}

The U.S. spends more on medical care than on any other single good or service. In 2017, U.S. medical care spending accounted for nearly $18 \%$ of the gross domestic product and $\$ 3.5$ trillion in total spending. ${ }^{8}$ Relative to its wealth, the U.S. spends well more than other OECD nations-twice as much as a comparable country average and 25 percent more than its closest peer nation, Switzerland. ${ }^{9}$ Yet, most of these other countries outperform the U.S. on key health

${ }^{6}$ United States Census, Health Insurance Coverage in the United States: 20175 (2018), at https://www.census.gov/content/dam/Census/library/publications/2018/demo/p60-264.pdf (last accessed July 30, 2019).

${ }^{7}$ See Timothy Jost, Access to Health Insurance and Health Benefits in OxFORD HANDBOOK OF U.S. HEALTH LAW (I. Glenn Cohen, Allison K. Hoffman, and William M. Sage, eds. 2017).

${ }^{8}$ Centers for Medicare \& Medicaid Services, NHE Fact Sheet Historical NHE 2017, at https://www.cms.gov/research-statistics-data-and-systems/statistics-trends-andreports/nationalhealthexpenddata/nhe-fact-sheet.html.

${ }^{9}$ Bradley Sawyer and Cynthia Cox, Peterson-Kaiser Health System Tracker, How Does Health Spending in the U.S. Compare to Other Countries? (2018), at https://www.healthsystemtracker.org/chart-collection/healthspending-u-s-compare-countries/\#item-start. 
outcomes, including life expectancy and infant mortality, as well as subjective patient experience. ${ }^{10}$

A major part of the problem in the U.S. is outsized prices that impede affordability, and thus access. Although utilization in the U.S. is generally not more than elsewhere, prices for medical services and goods in the U.S. are many time those in peer nations. ${ }^{11}$ For the most part, the U.S. has no central, regulatory price controls. ${ }^{12}$ Each insurance program, public and private, must separately negotiate rates with every provider. And the largest public insurance program, Medicare, has statutory restrictions that prevent the government from regulating prices on prescription drugs. The U.S. strategy has been to look to the market and competition to check prices, but this strategy has not worked well. ${ }^{13}$

Another part of the problem can be explained by how people access, and do not access, medical care in the U.S. A century ago, people who needed medical care simply paid for it. After a century of medical advances and the growth of a medical industry of hospitals, drugs, and devices, medical care had become so expensive, very few people could afford to pay for it outof-pocket. For most people, having good health insurance has become a necessary gateway to accessing good medical care, ${ }^{14}$ and for many doctors and hospitals, it is the key to being paid.

For most Americans, the first request when they go to a doctor or hospital is for their insurance card. In fact, some hospitals will not admit someone for care without proof they can pay. The average price of normal childbirth in the U.S. is over $\$ 10,000$ and coronary bypass surgery costs on average over $\$ 78,000 .{ }^{15}$ The annual per person spending on medical care is over $\$ 10,000 .{ }^{16}$ Compare this amount to the median household income, which before taxes

\footnotetext{
${ }^{10}$ Eric C. Schneider et al., The Commonwealth Fund, Mirror, Mirror 2017: International Comparison Reflects Flaws and Opportunities for Better U.S. Health Care 8-9 (2017). Marian F. MacDorman et al., Is the United States Maternal Mortality Rate Increasing? Disentangling Trends from Measurement Issues, 128 OBSTAT. GYNECOL. 447, 453 (2016).

${ }^{11}$ Gerald F. Anderson et al., It's Still The Prices, Stupid: Why The US Spends So Much on Health Care, And a Tribute to Uwe Reinhardt, 38 HEALTH AFF. 87 (2019).

12 Some states, like Maryland, have experimented with price controls.

${ }^{13}$ Allison K. Hoffman, Health Care's Market Bureaucracy, 66 UCLA L. REV. _ (forthcoming 2019).

14 John A. Nyman, The Value of Health Insurance: The Access Motive, 18 J. HEALTH Econ 141 (1999).

${ }^{15}$ Sarah Kliff and Soo Oh, America's Health Care Prices are Out of Control. These 11 Charts Prove it, Vox (2018), at https://www.vox.com/a/health-prices (last accessed July 25, 2018).

${ }^{16}$ Centers for Medicare \& Medicaid Services, NHE Fact Sheet Historical NHE 2017, at https://www.cms.gov/research-statistics-data-and-systems/statistics-trends-andreports/nationalhealthexpenddata/nhe-fact-sheet.html (last accessed July 30, 2019).
} 
was $\$ 57,652$ in $2017 .{ }^{17}$ The lowest quartile of earners had a mean income of just over $\$ 13,000$ and the second quartile of just over $\$ 35,000 .{ }^{18}$ For this majority of Americans, paying for medical care out-of-pocket is not an option. This Part will thus primarily focus on how insurance-public and private-defines access to care.

Section A briefly describes what people without health insurance do to pay for care. Section $B$ offers an overview of private and public insurance as a primary gateway to access medical care, including how it developed, how it evolved with the passage of the ACA, and how it has continued to evolve after the ACA's passage. Section C explains how the heterogeneity in health insurance in the United States exacerbates inequitable access, even among the insured. The final Section C. 2 considers why this inequitable picture remains and whether it will persist in the future.

\section{A. The Uninsured and Access to Medical Care}

Even with the primacy of health insurance, there are a few other ways that people can access care without health insurance to pay for it. First, some people receive charity care through free clinics, volunteer services offered by providers, fee waivers from hospitals' charity care programs, or drug assistance programs. All of these types of charity care, however, are contingent and extremely limited in scope.

Second, for select populations and some low-income patients, the government provides care directly, such as through the Indian Health Service (IHS) for over 2.5 million federallyrecognized American Indians and Alaska Natives, ${ }^{19}$ Veterans Health Administration (VHA) for over 9 million people who served for a designated period of time in the active military, naval or air service and were not dishonorably discharged, ${ }^{20}$ and through federally-qualified community health centers (FQHC). The IHS and VHA provide a full range of free or highly-subsidized inpatient and outpatient health care services in designated facilities. The VHA has, for example, 170 medical centers and over 1000 outpatient sites. ${ }^{21}$ FQHCs, in contrast, are federally-funded safety nets that offer mostly outpatient care on a sliding scale basis.

${ }^{17}$ United States Census Bureau Quick facts, at https://www.census.gov/quickfacts/fact/table/US/PST045217 (last accessed July 25, 2018).

18 United States Census Bureau, Historical Income Tables: Households, Table H-3 Mean Income Received by Each Fifth and Top 5 Percent, at https://www.census.gov/data/tables/time-series/demo/incomepoverty/historical-income-households.html (last accessed July 30, 2019).

${ }^{19}$ IHS Profile, Indian Health Services, at https://www.ihs.gov/newsroom/factsheets/ihsprofile/

${ }^{20}$ About VHS, Veterans Health Administration, at https://www.va.gov/health/aboutvha.asp.

${ }^{21} / d$. 
Public provision of care used to be more common in the U.S. In the early $20^{\text {th }}$ Century, a majority of hospitals were operated by state or local governments. But public provision has receded due in part to a constellation of political interests. ${ }^{22}$ The very term "socialized medicine" has been coopted in the U.S. as the rallying cry to reduce or contain the government's role in the provision of medical care even in areas where the government is already involved, such as the regulation of private insurance.

Third and finally, in some cases, people can and still do pay for care out-of-pocket. They do so in a variety of circumstance, ranging from people with financial resources paying for elective or concierge care to people without, or with poor, insurance coverage patching together funding for care in any way possible.

\section{B. Map of Public and Private Financing}

The U.S. health insurance system is a convoluted map of different sources of public and private health care financing. Unlike in most other countries, the public system in the U.S. is neither universally available nor primary. The maze of coverage sources is confusing even for students of the U.S. System, as evinced by the fact that it will take several pages just to describe its basics.

\section{The Evolution of a Fragmented System}

Although all countries have a mix of public and private financing for health care, the U.S. is the only nation among its peers that lacks a universal public system to create access to basic care and, not surprisingly, the only one among peers that tolerates high rates of uninsurance. ${ }^{23}$ Most other peer nations finance care with universal social insurance through taxes (either earmarked or general revenue), such as in France, Canada, or Australia. Alternately, some provide care directly through government-owned hospitals and employed physicians, as in the UK's socialized medical systems. The U.S. does neither of these things.

Even the countries that on first blush might look more like the U.S. system because of the centrality of the private market and options, such as Switzerland, are fundamentally different. After the passage of the ACA with its mandate that most people have health insurance and its creation of regulated marketplaces for purchase, many people attempted to analogize the U.S. system to the Swiss one.

22 Jost, supra note 7 , at 7.

${ }^{23}$ Even in Switzerland, where people buy insurance from private insurance companies, the uninsurance rate is usually only 1-2 percent. If you google, "uninsurance rate Switzerland," in fact, Google reports back on the unemployment rate. 
The Swiss system is similar only to the extent that each person in Switzerland must purchase a health insurance policy directly from an insurer and each person has a choice among dozens of insurers. ${ }^{24}$ Beyond that, the two diverge. The Swiss government mandates basic benefits for all plans, sets physician rates through a national fee schedules and maximum pricing for hospitals and pharmaceuticals, and approves the community-rated insurance premiums. ${ }^{25}$ The U.S. does regulate benefits in the exchange plans but does not regulate fees or approve premiums. Unlike in the U.S., Swiss insurers are all not-for-profit organizations that must return surplus to policyholders. ${ }^{26}$ Coverage is highly subsidized and nearly universal, guaranteed by a strongly-enforced mandate that, in a very unamerican way, garnishes wages up to the amount of premiums if someone does not have insurance. Access to care does not vary significantly, except with respect to what are considered "amenities," like single-room occupancy in hospitals, or services like dental care. ${ }^{27}$ The Swiss system is in effect a social insurance program, just with an element of choice built in. The Dutch and German systems, which also offer some choice of health plan, are also social insurance. ${ }^{28}$ The U.S. system, even if it shares some surface characteristics like choice of private insurance plans in a marketplace, is fundamentally different in critical philosophical and practical ways.

At the time that other countries were developing social insurance systems, the U.S. faltered. Despite repeated attempts over the twentieth century to create a national system for healthcare financing in the U.S., none succeeded and different forms of health care financing developed incrementally and over time. ${ }^{29}$ Over the course of the $20^{\text {th }}$ century, public insurance programs were created to pay for care for populations considered especially vulnerable and private insurance filled in from there.

President Lyndon Johnson signed the bedrock programs of public financing, Medicare and Medicaid, into law in 1965 as part of his Great Society, and the programs have since been

\footnotetext{
${ }^{24}$ Nikola Biller-Andorno \& Thomas Zeltner, Individual Responsibility and Community Solidarity-The Swiss Health Care System, 373 NEW Eng .J. Med. 2193, 2195 (2015).

${ }^{25}$ Id.

${ }^{26}$ Id. at 2195.

272196.

${ }^{28}$ Timothy Stoltzfus Jost, The Experience of Switzerland the Netherlands with Individual Health Insurance Mandates: A model for the United States?, at http://law2.wlu.edu/deptimages/Faculty/Jost\%20The\%20Experience\%20of\%20Switzerland\%20and\%20the\%20Net herlands.pdf (last accessed May 22, 2018).

${ }^{29}$ See, e.g., Stuart Altman \& David Schactman, Power, Politics, and Universal Health Care: The Inside Story of A Century-Long Battle (2011), David Blumenthal \& James A. Morone, The Heart of Power: Health and Politics in the Oval Office (2009); Paul Starr, Remedy and Reaction: the Peculiar American Struggle Over Health Care Reform (2011).
} 
considered the greatest success of $20^{\text {th }}$ Century U.S. health reform. ${ }^{30}$ Even so, Medicare and Medicaid were a failed attempt at universalism. ${ }^{31}$ They set out to pay for healthcare for the elderly, the "deserving poor," - focusing on those who are young or pregnant-and for people with disabilities. In other words, Medicare and Medicaid selected out more vulnerable populations for public insurance. This cabining out of more vulnerable populations is in direct contrast with European models based on solidarity, where the healthy and wealthy crosssubsidize others in insurance pools.

Medicare, which pays for medical care for 57 million older Americans and some people with disabilities, is itself a constellation of many parts and many rules. Medicare Part A pays for hospital benefits, and enrollment is free and automatic for all persons who contributed sufficient payroll taxes during their working years. Medicare Part B pays for outpatient care and is optional, although nearly all eligible people enroll. It is financed by general tax revenue and monthly premiums, which are income adjusted. Both of these parts have cost-sharing requirements when people use care, which leave enrollees vulnerable to potentially high outof-pocket spending for using medical care. For example, in 2019, Part A includes a deductible of $\$ 1364$ per hospitalization. ${ }^{32}$ For hospital stays longer than 60 days, beneficiaries have cost sharing of $\$ 341$ per day for days 61 to 90 and $\$ 682$ per day beyond that. ${ }^{33}$ For outpatient care, beneficiaries pay a $\$ 185$ deductible in 2019 and $20 \%$ coinsurance for most services. ${ }^{34}$ Ninety percent of all retirees obtain private supplemental insurance coverage, through various forms, to help fill in these gaps. ${ }^{35}$

Medicaid has become the largest single insurer in the United States through a series of incremental expansions. ${ }^{36}$ Medicaid is funded jointly by the state governments and through federal "matching funds," which are at least as much as what the states spend, and more in many states. ${ }^{37}$ It began as a program to cover poor people who were receiving cash welfare,

30 Social Security Amendments of 1965, Pub. L. No. 89-97, 79 Stat. 286 (1965) (codified as amended at 42 U.S.C. $\S \S 1395,1396(2012))$.

31 Theodore R. Marmor, The Politics of Medicare 95-96 (1970).

322019 Medicare Costs, MediCARE.Gov, https://www.medicare.gov/pubs/pdf/11579-medicare-costs.pdf (last visited July 30, 2019).

${ }^{33}$ Id.

${ }^{34}$ Id.

35 Juliette Cubanski et Al., Henry J. Kaiser Family Found., Medicare Chartbook 60 (4th ed. 2010).

${ }^{36}$ Cindy Mann \& Deborah Bachrach, Medicaid as Health Insurer: Evolution and Implications, Commonwealth Fund To The Point (July 23, 2015).

${ }^{37}$ Laura Snyder \& Robin Rudowitz, Medicaid Financing: How Does it Work and What are the Implications?, Kaiser Family Foundation Issue Brief (May 20, 2015). 
including children and their parents and the elderly, blind, and disabled. Over time, additional categories of people were added, including pregnant women and children in families with slightly higher incomes. ${ }^{38}$

With the ACA, Medicaid eligibility was extended to all non-elderly poor and the income threshold was lifted up to $138 \%$ of the federal poverty level (just over $\$ 35,000$ USD for a family of four in 2019). In a legal challenge to this provision, the Supreme Court found it unconstitutional, beyond Congress's authority. The Court in a case called NFIB v. Sebelius, held that the conditions of the expansion, which required states to expand eligibility to this entire population or else lose their current federal funding, were like a "gun to the head" of the states and thus a coercive use of federal spending power. ${ }^{39}$ The effect of the decision in this case was to make the expansion optional. States could expand and, if they did, get additional federal matching funds, or not and maintain their current programs. As of the end of July 2019, 33 states and Washington DC had expanded; 17 had not yet. ${ }^{40}$ Even with the decision in NFIB $v$. Sebelius, Medicaid has become an increasingly universal program for the poor, regardless of their welfare status, and the number one financing source for long-term care.

The creation of Medicare and Medicaid to cover limited populations catalyzed a halfcentury of efforts to fill in the gaps. The Children's Health Insurance Program (CHIP) was created in 1997 for children just above Medicaid income thresholds, Medicare Part D was added in 2003 to provide prescription drug benefits to elders, and most recently, the ACA expanded Medicaid and filled in coverage gaps in the Medicare Part D program. Now, just over one-third of the population has public health insurance, mostly with Medicare and Medicaid and a small number with military or veteran's coverage. ${ }^{41}$

Private financing-in the forms of employer-sponsored health insurance (ESI), individual health insurance, out-of-pocket payments, and charity care-fills in remaining gaps. Health insurance developed as an employment benefit throughout the $20^{\text {th }}$ Century and has become deeply entrenched as such. While employers are not required to offer their employees health

${ }^{38}$ Sara Rosenbaum \& Benjamin D. Sommers, Rethinking Medicaid in the New Normal, 5 ST. LOUIS J. HEALTH L. \& POL'Y 127, 138 (2011).

${ }^{39}$ NFIB v. Sebelius, 567 U.S. 519 (2012).

${ }^{40}$ Kaiser Family Foundation, Status of State Action on the Medicaid Expansion Decision as of July 27, 2018, at https://www.kff.org/health-reform/state-indicator/state-activity-around-expanding-medicaid-under-theaffordable-careact/?currentTimeframe=0\&sortModel=\%7B\%22colld\%22:\%22Location\%22,\%22sort\%22:\%22asc\%22\%7D (last accessed August 16, 2018).

${ }^{41}$ Jessica C. Barnett \& Edward R. Berchick, Current Population Reports, Health Insurance Coverage in the United States: 20162 (2017), at https://www.census.gov/content/dam/Census/library/publications/2017/demo/p60-260.pdf 
insurance, many do because expenditures on health benefits are excludable from taxes for both the employer and employee. The beneficial tax treatment means that health benefits have become a less expensive way to compensate employees. ${ }^{42}$ Over half of Americans have private health insurance, ${ }^{43}$ most of whom have ESI. ${ }^{44}$

Without access to public insurance or ESI, people who want health insurance are left to seek it out on their own, directly from a private insurance company. Six to seven percent of the non-elderly (about 15 million people) had health insurance through this "individual-market" prior to the passage of the ACA. ${ }^{45}$ Historically, individual-market coverage was relatively more expensive than $\mathrm{ESI}$, in part because administrative costs were as high as 15-20 percent of total costs. This cost arose in part because, before the ACA, insurers could underwrite and exclude people based on their health, with few legal restrictions. ${ }^{46}$ As many as three in five people who applied for individual health insurance before the ACA could not afford the high premium prices or were denied coverage, and many people remained uninsured or underinsured. ${ }^{47}$

\section{The ACA and Blurring of Public and Private Insurance}

The lines between public health insurance and private insurance have blurred over time. ${ }^{48}$ Public health insurance is increasingly outsourced to private insurers as administrators and reliant on private-market tools to attempt to control spending. As one example, programs like Medicaid have increasingly looked to private managed care companies to administer benefits,

${ }^{42}$ By one estimate, health insurance costs employers approximately $\$ .65$ per dollar of benefits. Jonathan Gruber, Covering the Uninsured in the United States, 46 J. ECON. LITERATURE 571, 574 (2008).

43 Jessica C. Barnett \& Edward R. Berchick, Current Population Reports, Health Insurance Coverage in the United States: 20162 (2017), at https://www.census.gov/content/dam/Census/library/publications/2017/demo/p60-260.pdf

${ }^{44}$ Id.

45 Paul Fronstin, Sources of Health Insurance and Characteristics of the Uninsured: Analysis of the March 2009 Current Population Survey, EBRI ISSUE BRIEF, no. 334, Sept. 2009, at 5.

${ }^{46}$ See, e.g., Melinda Beeuwkes Buntin et al., The Role of the Individual Health Insurance Market and Prospects for Change, 23 Health Aff. Nov.-Dec. 2004 at 79, 81; Sara R. Collins et Al., The Commonwealth Fund, SQueEzed: Why Rising Exposure to Health Care Costs Threatens the Health and Financial Well-Being of American Families 3-4 (2006).

${ }^{47}$ Michelle M. Doty et al., Failure to Protect: Why the Individual Insurance Market Is Not a Viable Option for Most U.S. Families, CommonWEALth Fund Pub. No. 1300 at 1-3 (2009).

${ }^{48}$ Amy Monahan, The Interaction Between Public and Private Health Insurance in THE OXFORD HANDBOOK OF U.S. HeALtH LAW (I. Glenn Cohen, Allison K. Hoffman, and William M. Sage, eds. 2017). 
since permitted by law in $1997 .{ }^{49}$ In 2016 , over three-quarters of the 80 million beneficiaries were enrolled in managed care plans. ${ }^{50}$

Medicare reforms also have integrated private industry, in their case with the goal that competition would offer a means to control spending. In 1997, Congress created a new program in Medicare called Medicare+Choice (now Medicare Advantage), which allowed people to choose to get their Medicare coverage from private managed care plans. These plans cover the traditional benefits under Parts $A$ and $B$, and sometimes also Part $D$ drug benefits. They also provide supplemental coverage to fill in the out-of-pocket costs not covered by traditional Medicare. The theory, in establishing these plans, was that competition among private insurers to gain Medicare beneficiary enrollment would drive up quality and down costs. This theory has faced many problems in practice. For many years these plans were excessively overpaid. Especially in the initial years, the private plans attempted to select out healthier populations to maximize profit. Even without these problems, enrollees have difficulty differentiating among plans, and often make poor choices.

As public insurance is shaped by private industry and market-based strategies, private health insurance has been increasingly regulated and, after the ACA, individual market coverage in particular has begun to take on qualities of social insurance. The ACA transformed the individual-market, regulating what coverage insurers could offer, to whom, and at what cost.

Prior to the ACA, apart from a few federal laws, ${ }^{51}$ most of the regulation of health insurance, especially in the individual market, was reserved for the states by a federal law called the McCarran-Ferguson Act. ${ }^{52}$ The ACA in effect federalized much of the regulation of the health insurance to make individual-market coverage more affordable and meaningful. The ACA required insurers to take all applicants despite pre-existing conditions, a requirement known as "guaranteed issue." 53 It eliminated underwriting and allows premium variation based on only

${ }^{49}$ Balanced Budget Act of 1997, Pub. L. No. 105-33.

${ }^{50}$ Center for Medicare \& Medicaid Services, Medicaid Managed Care Enrollment and Program Characteristics 11 (2016).

${ }^{51}$ Health Insurance Portability and Accountability Act of 1996, Pub. L. No. 104-191, 110 Stat. 1936 (1996). Other examples include The Employee Retirement Income Security Act of 1974, which set minimum standards for employee health plans, and The Genetic Information Nondiscrimination Act of 2008, which restricted the use of genetic information in health underwriting. Employee Retirement Income Security Act of 1974, Pub. L. No. 93-406, 88 Stat. 829 (1974); Genetic Information Nondiscrimination Act of 2008, Pub. L. No. 110-233, 122 Stat. 881 (2008).

52 McCarran-Ferguson Act, ch. 20, 59 Stat. 33 (1945) (codified as amended at 15 U.S.C. §§ 1011-1015 (2012)).

53 Patient Protection and Affordable Care Act § 1201, 42 U.S.C. § 300gg (2012). 
four factors: age, geography, family size, and tobacco use status. ${ }^{54}$ Even if an insurer devised a way to cherry-pick out healthier applicants, the law intended to disgorge any resulting profits through reinsurance and risk-adjustment arrangements. ${ }^{55}$ Policies were required to include a range of mandated benefits similar to those offered in most employer plans, in ten categories of "essential health benefits," including preventive care without cost sharing, and were no longer allowed to impose annual or lifetime coverage limits on these mandated benefits. ${ }^{56}$

Finally, the ACA's individual mandate required that most Americans carry health insurance that offers "minimum essential coverage," or else pay a penalty, which proved one of the most contentious parts of the law. ${ }^{57}$ Some people referred to the mandate as the linchpin of the individual market because it would resist adverse selection, where people would wait until they knew they needed medical care to buy coverage. The mandate intended to promote heterogeneous risk pools by requiring everyone to buy in, regardless of immediate medical need.

In addition, the ACA provided subsidies to help lower-income individuals comply with this mandate. Anyone who earns from 100 to $400 \%$ of the federal poverty level $(\$ 12,490-\$ 49,960$ for an individual) and does not have another adequate source of insurance, such as through an employer or Medicaid, is eligible for subsidized premiums. Lower-earners $(100-250 \%$ of the federal poverty level) are also eligible for cost-sharing reductions to help them pay for the deductibles or other cost-sharing when they use medical care. ${ }^{58}$ The ACA established exchanges for the sale of the newly regulated policies where, in theory, private insurers would compete to offer plans to new enrollees.

Nearly 200 pages of the ACA are devoted to the endeavor of regulating private insurance and, in particular, revamping the individual market into a quasi-public enterprise. The ACA left the majority of employer plans largely untouched, with several exceptions. The regulation that proved most contentious was one that all plans, including employer plans, cover contraceptive products and services, as part of a general requirement to cover preventive care without cost sharing. The law exempted houses of worship from this requirement and created an accommodation for religious nonprofit organizations. Other employers, including Hobby

${ }^{54}$ Id.

55 Id. at $\S 1341-42,42$ U.S.C. $\S 18061-62$.

${ }^{56}$ Id. at § 1302, 42 U.S.C. § 18022; Id. at § 1001, 42 U.S.C. § 300gg-11 (2012), 42 U.S.C. § 300gg-13 (2012).

57 Id. at $\S 1501,26$ U.S.C. $\S 5000 A$ (2012). Some people are exempted from the penalty for reasons including religious objection or affordability, defined as when premiums cost over eight percent of household income. Id.

58 Id. at $\S 1401,26$ U.S.C. $\S 36 B$ (providing for "premium tax credits"); Id. at § 1402, 42 U.S.C § 18071 (providing for "cost-sharing reductions"). 
Lobby-a closely held company, challenged this requirement as in violation of their religious freedom and prevailed in the Supreme Court. ${ }^{59}$

The ACA's complex path to a simple goal of more universal coverage is unusual when viewed comparatively, but it offered an incremental way to pursue transformative policy goals. Optically, the ACA preserved preexisting private market structures and values. Practically, however, it bent and reshaped them to create more universal and meaningful access to health care in the U.S. Yet, in large part because of the multifaced regulatory efforts needed to achieve their goals, the ACA policies to expand insurance coverage have been vulnerable.

\section{ACA Challenges}

Even in the best case scenario, the ACA's hoped-for gains were hard to achieve. In addition to the legal challenges discussed above, and numerous others, the ACA has faced a series of technical and political challenges in its efforts to expand access.

For example, the initial roll out of the exchanges were an infamous disaster, with technical problems hampering enrollment. Even once the exchanges were running, people have struggled to choose health plans, often choosing plans in a way that seems contrary to their own interests. Others have struggled to afford plans on the exchanges, especially if they are receiving no or little premium subsidy support. Reinsurance and risk-adjustment payments have been underfunded and underpaid. ${ }^{60}$ In part because of these problems, some states have faced low insurer participation and some states even had regions with no participating insurers. As discussed above, the Supreme Court decision in NFIB v. Sebelius dealt a blow to the Medicaid expansion. Even under the best conditions, the ACA's piecemeal approach to expanding coverage was a laborious process.

Even worse, when the Trump Administration succeeded the Obama Administration, it worked to undermine the ACA's insurance expansion efforts, revealing simultaneously the durability of some of its policies and its greatest fault lines as well. Following President Donald Trump's election in November 2016, the Republican majority in the U.S. Congress pursued a wholesale repeal of the ACA. These efforts failed in part because of popular resistance, especially to the repeal of the Medicaid expansion, which was enabling more low-income people to access medical are. The one area where Congress did succeed was to repeal the individual mandate, as a part of tax reform, carving out one of the many interlocking pieces the ACA put in place to reform the individual market.

${ }^{59}$ Burwell v. Hobby Lobby, 573 U.S. (2014).

60 Timothy Jost, Risk Corridor Claims by Insurers Far Exceed Contributions, HeAlth AffalRs Blog (Oct. 1, 2015), http://healthaffairs.org/blog/2015/10/01/implementing-health-reform-risk-corridor-claims-by-insurers-farexceed-contributions/. 
Akin to the repeal of the individual mandate by Congress, the Trump Administration has also been working a slow dismantling of the ACA reforms to the individual market, through a series of technocratic rules that will make it harder for insurers to participate in these markets and harder for people to afford coverage and to access care even when they have it. For example, the Administration has issued several rules that allow for the sale of plans with less comprehensive coverage than the ACA required. Although the Secretary of the Department of Health and Human Services claims that these plans will create more affordable coverage options, ${ }^{61}$ the result of these efforts will be that many people have health insurance inadequate to pay for the care they need. These options for "bare-bones" coverage also encourage adverse selection on the exchanges, where healthier people buy minimal coverage and sicker people stay in more comprehensive plans, whose premiums will become more expensive over time.

Another round of administrative efforts has focused on scaling back the Medicaid expansion, and undermining Medicaid program enrollment altogether. The primary means for doing so is through the use of the Medicaid waiver program, known as Section 1115 waivers, which allow states to experiment with new benefits and program designs. In a letter to state Medicaid directors issued in January 2018, the Administration encouraged states to use Section 1115 waivers to experiment with work and community-engagement requirements for beneficiaries. No previous administration would allow states to adopt these requirements, which are impossible for many of the vulnerable Medicaid population to meet and which create paperwork burdens and hurdles that result in disenrollment. In Arkansas, which started implementation in June $2018,29 \%$ of the targeted population failed to meet requirements in the first month of implementation. ${ }^{62}$ If these programs survive legal challenges to their legitimacy-and they may or may not-they will winnow out the Medicaid population through gradual attrition.

The Trump Administration has also taken aim at the contraceptive coverage requirement. In October 2017, the Administration issued new regulations that significantly expanded the employers who were exempted from the requirement. Newly exempted were all nonprofit and closely-held organizations with objections based on religious or moral beliefs and all publiclytraded for-profit corporations with religiously-based objections. This new rule was contentious both because of its substance, including its arguably discriminatory effects against women employees and their health needs, and because it was issued without an opportunity for public comment, as is required under the Administrative Procedure Act (APA).

${ }^{61}$ Alex M. Azar, Obamacare Forgot About You. But Trump Didn't, WALL St. J. (August 15, 2018).

62 Erin Brantley \& Leighton Ku, A First Glance at Medicaid Work Requirements in Arkansas: More than OneQuarter Did Not Meet Requirement, HeALTH AfFAIRS Blog (August 13, 2018). 
All of these actions incrementally scale back insurance coverage and will limit access to affordable medical care. All of these administrative actions have also been challenged in court, based on procedural and substantive grounds, and challengers have prevailed in early decisions. These new rules have been vulnerable in large part because of the Administration's short-cutting procedural requirements under the APA. For example, initial rulings struck down the approval of work requirements in the states of Kentucky, Arkansas, and New Hampshire and the new contraceptive coverage rules in courts in California and Pennsylvania, all because the courts found they were promulgated in violation of the APA-without justification.

It is impossible to predict where this struggle between the ACA's efforts to expand insurance coverage and subsequent efforts to undermine it will pan out. What is clear is that it illustrates the deep disagreement in the United States about who should be guaranteed access to what medical care. It is also clear that the gradual chipping away at the ACA, since its passage, will further embed the inequity of access among Americans.

\section{Implications of Inequitable Coverage}

\section{Heterogeneity of Insurance and Access}

Even as the overall number of Americans with health insurance increases, the heterogeneity of how people get insurance preserves meaningful differences. Being insured does not guarantee the same access for everyone. A number of attributes make it easier or harder for people with insurance to access and to afford medical care, including what type of insurance they have, where they live, and how much disposable income they have to pay for cost-sharing. It would be impossible to touch on all of the ways access differs among insured people in this chapter, but the below highlights a few critical aspects.

One way that the many sources of coverage detailed above differ is in their "provider networks." Insurers typically contract with a limited number of physicians, hospitals, and other providers to obtain discounted rates for their customers. When patients receive care from "innetwork" providers, they pay much less in out-of-pocket costs than if they receive care from "out-of-network" providers. As a practical matter, then, an individual's choice of provider is restricted by the insurer's network.

In addition, as discussed in Part III below, providers and hospitals have significant discretion over which patients they accept for medical care, especially for non-emergency care. Some providers choose to accept only patients with private insurance and an increasing number of providers, especially those in high-demand practice areas and cities with more demand than supply, do not accept insurance at all, or charge retainer fees for a patient to join a practice. One leading national hospital, the Mayo Clinic, recently announced that it will prioritize 
privately-insured patients over those on Medicare or Medicaid. ${ }^{63}$ Others do so whether they make that policy explicit or not. Providers and facilities that accept public insurance are more likely to accept Medicare than Medicaid, since Medicare's reimbursement rates are higher. Rates of provider participation are highest in employer plans, followed by ACA marketplace plans, and lowest in Medicaid. ${ }^{64}$ Among participating providers, availability of appointments was again highest for ESI and lowest for Medicaid.

Variability in which benefits plans cover likewise can be significant and is defined in ways that allow more variability and less transparency than how benefits are defined in Europe. For example, employer plans have discretion for the most part to cover-or not cover-whatever benefits they would like. Although most large employers cover a wide range of services, employers could choose to offer a very limited set of benefits. Furthermore, even though the ACA set a baseline by requiring all individual-market plans to cover the ten categories of essential health benefits, it gave states considerable discretion in deciding what exactly would fall into these categories. Furthermore, it did not require employer plans to cover these benefits. Even though most do, they are not legally required to do so.

Plans also vary on what kind of legal recourse is available when medical claims are denied. Although ESI is superior to other coverage in many way, beneficiaries have limited legal recourse and remedies when medical claims are denied by health plans. These plans, and the remedies for violations of plan terms, are governed by a federal law called the Employee Retirement Income Security Act of 1974 (ERISA). The Supreme Court has interpreted this law to shield health insurers from liability under state law for denials of coverage under employer plans. ${ }^{65}$ If members of an employer plan have their claims denied, their only recourse is to pay for the medical care denied and seek reimbursement through federal court under the terms of ERISA's remedy provisions. If they are physically harmed by the plan's denial of care, there is no legal remedy for this harm. For non-employer plans, such as Medicaid plans or ACA exchange plans, beneficiaries still have access to state courts for coverage denials and a fuller range of remedies.

Finally, someone's resources-financial and intellectual-can have a significant impact on their access to medical care. Can they afford to pay the cost-sharing under their plans? Can they navigate the complexity of the system and their insurance plans? Can they take time off work to

${ }^{63}$ Casey Ross \& Andrew Joseph, Mayo Clinic: Privately Insured Patients to Get Priority over Medicaid, Medicare Patients, STAT (March 15, 2017).

64 Daniel Polsky et al., Scope of Primary Care Physicians' Participation in the Health Insurance Marketplaces, 37 HeALTH AfFAirs 1252 (2018).

${ }^{65}$ Aetna v. Davila, 542 U.S. 200 (2004). 
get to doctors and other appointments, especially if their plans have a more restricted network that requires them to travel farther for care?

The multifaceted approach to health care financing in the United States not only creates inequitable results, it also undermines solidarity, confuses patients, and creates tremendous overhead costs and burdens for providers. It obscures inequities in the system, perhaps intentionally. This structure has been built through incremental attempts to move toward more universal coverage, but the end result still leaves significant gaps, both in who is covered and in how meaningfully the coverage provides access to care.

\section{The Future of Health Insurance in the United States}

This fragmented system is a result of various factors that will continue to hamper efforts at creating a more uniform structure for financing care in the United States. That said, the shortcomings of the ACA and its belabored efforts to build out private insurance, followed by efforts to dismantle ACA, could create opportunities. As the ACA health insurance exchanges falter, politicians, policy experts, and pundits are increasingly looking toward solutions that would expand public health insurance and move the United States financing system closer to its European counterparts.

These ideas build on the existing Medicaid and Medicare programs, extending public health insurance to more people. One popular idea is a Medicaid buy-in to replace the ACA marketplaces. Since most states have well-established Medicaid programs and some have had trouble ensuring sufficient options in their exchanges, Medicaid buy-in could ensure access to more affordable options for exchange enrollees.

Other proposals build on the existing Medicare program, either allowing buy-in by younger populations or, more transformatively, creating a Medicare-for-All program, which many progressive candidates running for office, including U.S. Sen. Bernie Sanders, have taken up as their mantle. These types of expansion of public insurance will continue to meet significant resistance by insurers and hospitals, whose livelihood could be threatened by them. And they are certainly not a silver bullet. These programs have their own problems that would become even more detrimental if they expand. And efforts to finance them through new tax revenue will inevitably be highly unpopular. Yet, it is possible that the light that the ACA has shone on problems in health care access in the U.S. and the difficulty in remedying them through private market reforms that require constant technocratic tinkering, may shift the political balance. 


\section{Draft in Progress}

\section{The TREATMENT Relationship}

Of course, more than the financing structure affects access to health care. Both medical practices and legal requirements can expand or contract access to care. This Part discusses the legal obligations that have developed through common and statutory law that provide access to care under certain conditions. It focuses in particular on the doctor-patient relationship, specifically, the legal rules that govern the structure of the treatment relationship: the duty to treat, and the formation, modification and termination of the relationship. ${ }^{66}$

\section{A. Constitutional Rights of Access}

Unlike in many other countries, in the U.S. there is no constitutional obligation for government to fund or provide health care. The Supreme Court has firmly stated that "the Constitution imposes no obligation on the States to pay ... any of the medical expenses of indigents." 67 This is because the Due Process Clause traditionally has been seen as protecting individuals from improper government interference ("negative" liberties), rather than generating entitlements to state-conferred assistance or benefits ("positive" liberties). ${ }^{68}$

Nevertheless, violations of negative liberties can be argued in many contexts of health care regulation. One court found a generalized constitutional right to be free of poorly justified state restrictions on medical decisionmaking. ${ }^{69}$ The court struck down a law that allowed only licensed physicians to practice acupuncture as an infringement of patients' right to "obtain or reject medical treatment," which the court found was encompassed by the right to privacy identified in Roe v. Wade. Most courts, however, require only a "rational" justification for such restrictions, ${ }^{70}$ and, in any case, they view the state's concern to protect health as a "compelling" interest, ${ }^{71}$ so these types of argument rarely succeed. For instance, courts have upheld state bans on alternative cancer therapies that are probably harmless but thought to be

66 This portion of the chapter is based on materials previously published as Mark A. Hall, et al., Health Care Law and Ethics in a Nutshell ( $3^{\text {rd }}$ ed. 2011).

67 Maher v. Roe, 432 U.S. 464, 469 (1977).

${ }^{68}$ See also Deshaney v. Winnebago County Department of Social Services, 489 U.S. 1989 (echoing the foregoing).

${ }^{69}$ Andrews v. Ballard, 498 F.Supp. 1038 (S.D.Tex.1980).

70 That is, as long as there is a conceivable justification for the policy, it is permitted.

${ }^{71}$ Even for fundamental rights, the state can override the right in order to promote a very important public interest. 
ineffective. ${ }^{72}$ And, the FDA may restrict patients' access to unapproved drugs, even if they are a dying patient's only hope. ${ }^{73}$

Even though there is no general constitutional right to health care, "when a State does decide to alleviate some of the hardships of poverty by providing medical care, the manner in which it dispenses benefits is subject to constitutional limitations" imposed by the Due -Process and Equal Protection Clauses of the Constitution. ${ }^{74}$ Thus, a publicly-funded hospital cannot arbitrarily discriminate in the patients it treats or in the services it provides. ${ }^{75}$

\section{B. Common Law and Statutory Duties to Treat Patients}

Although U.S. health care law is a largely "constitution-free zone," common law and statutory law have a great deal to say about patient's rights to be treated. A patient's right to receive treatment differs between paying and indigent patients. Paying patients, of course, have greater access. But certain obligations to treat are independent of the ability to pay, and for paying patients there remain some barriers based on race, disability and other factors. Thus, the ability to pay is not the primary issue in the following discussion. Nevertheless, access to medical care by the indigent is the subject of both explicit and implied attention in much of what follows.

\section{Doctors}

\section{a. The "No-Duty" Rule}

A doctor is generally under no duty to accept patients, regardless of the seriousness of their condition, their ability to pay, or the physician's basis for refusing. In the seminal decision, Hurley v. Eddingfield, which is still regarded as stating "good" (i.e., prevailing) law, the court affirmed the dismissal of a suit for damages on behalf of a would-be patient who died when a physician refused to treat her -- notwithstanding that the doctor had been her family physician in the past, was available to render care (and aware that other physicians were not), was told she was now seriously ill and relying on an expectation of treatment, gave no reason for the refusal, and was offered payment. ${ }^{76}$ The court reasoned that a physician's traditional freedom

${ }^{72}$ Cf. Rutherford v. United States, 442 U.S. 544 (1979).

${ }^{73}$ Abigail Alliance for Better Access to Developmental Drugs v. von Eschenbach, 495 F.3d 695 (D.C. Cir. 2008) (en banc).

${ }^{74}$ Maher, supra, 432 U.S. at 470.

75. See Memorial Hospital v. Maricopa County, 415 U.S. 250 (1974) (unconstitutional to refuse county health services to temporary residents)

${ }^{76}$ Hurley v. Eddingfield, 156 Ind. 416, 59 N.E. 1058 (1901). 
to select patients remained unaltered by the advent of state licensure law, which imposed no obligation on a physician "to practice at all or on other terms than he may choose to accept."

This "no-duty" rule tracks the historical absence, in American tort law, of any legal obligation to aid strangers in distress. Professional medical ethics reflect a similar policy: "Even the Hippocratic Oath, by which every doctor is morally bound, assumes a pre-existing relationship of patient and physician, which relationship in its inception is basically contractual and wholly voluntary," 77 and the AMA Principles of Medical Ethics leave a physician free "to choose whom to serve" (though they recognize an exception for emergencies).

Implicit in these articulations of the "no duty" rule is the axiom that, where a physician/patient (or hospital/patient) relationship does exist, there is a legal obligation to treat. This duty to treat is fiduciary in nature (sec. B.1.) and persists until the relationship is properly terminated (sec. A.6). Since the formation of the treatment relationship is foundational to the entire range of issues that make up law and medicine (including malpractice and most of bioethics), what constitutes "formation" is important.

\section{b. Formation of the Treatment Relationship.}

The court in Hurley v. Eddingfield, supra, absolved Dr. Eddingfield despite his having been the deceased's "family doctor" and the fact that the medical condition was active labor. This reflects the general rule that an established custom of past treatment does not oblige a doctor to treat a patient's future illnesses; doctor/patient relationships are specific to a "spell of illness" and must be established, or renewed, accordingly.

Within a given "spell," however, the law often requires very slight involvement before finding that a treatment relationship between patient and doctor (or hospital) has been formed. A patient's description of symptoms over the phone followed by a physician's brief instructions, a telephone call to a physician's office for the purpose of initiating treatment, or scheduling an appointment to treat a particular medical problem have all sufficed to support a fact-finder's inference that a doctor or hospital had undertaken to provide care. While little is generally required, the decisions are not uniform: courts have also found that no relationship arose where the call to a physician's office to schedule an appointment did not itself seek or generate medical advice, and that where a patient interpreted the physician's response to her telephone contact as a refusal to undertake care, the requisite "consensual" characteristic of the relationship was missing -- irrespective of the objective content of their communication.

Physicians' informal "curbside" consultations with colleagues normally will not establish a relationship between the patient and the consultee-physician. Courts fear that implying a treatment relationship out of limited, routine consultative contacts (of which the patient,

\footnotetext{
77 Agnew v. Parks, 343 P.2d 118, 123 (Cal.App.1959),
} 
incidentally, is often unaware) would chill a useful medical practice, to the detriment of patients and physicians alike. Of course, more formal physician referrals likely will result in legal recognition of the treatment relationship.

Finally, no treatment relationship customarily arises where physicians examine patients for the benefit of third parties. Thus, physicians conducting physical exams for insurance eligibility or for employment-related purposes generally are not held liable to the examinee for failure to treat, or for other medical errors or nondisclosures.

Exceptions have arisen, however. In the employment context, courts have implied a limited relationship, imposing a duty that extends only to disclosure of any test results that "pose an imminent danger to the examinee's physical or mental well-being," or have implied the relationship where the physician affirmatively undertook treatment or gave advice. At least one case held that an employer itself (in contrast to the examining physician) may be liable to the examinee for negligent failure to disclose a serious medical problem discovered in a preemployment exam. ${ }^{78}$ In contrast, another case found that a life insurer has no duty to disclose positive HIV test results to a policy applicant. ${ }^{79}$ However, the court, seemingly unaware of the "no duty" rule usually applied in such situations, suggested in dictum that if a physician (rather than the company) had been "directly involved," the court might find a duty to disclose such information, based on patients' expectations, professional ethics, and physician expertise in health matters. Of course, to the extent these policy rationales are persuasive, they undercut the no-duty rule that normally applies in these cases.

\section{Hospitals}

It is sometimes stated that the "no duty" rule documented above for physicians applies with equal force to hospitals. While this might have been true at one time (the older case law seems to say so, but it is not without ambiguity), this general "no duty" rule unquestionably is not the law now. Hospitals and other health care institutions, in contrast with physicians, operate under numerous sources of law (both statutory and court created) that prohibit the arbitrary refusal to admit patients.

As noted above, uninsured patients traditionally have relied on free care rendered by public or private hospitals. Most larger cities maintain a municipal hospital that is obliged to treat all patients regardless of the ability to pay, and many smaller localities historically provided for the uninsured by compensating private hospitals for treating the poor. This local largesse has become overtaxed, however, and so many municipalities have greatly scaled back or eliminated their support for medically indigent residents. Private hospitals have a long tradition of caring

\footnotetext{
78 Dornak v. Lafayette General Hospital, 399 So.2d 168 (La. 1981).

${ }^{79}$ Deramus v. Jackson Nat. Life Ins. Co., 92 F.3d 274 (5th Cir. 1996). 
for the poor, but their capacity for charity care has been stretched thin by reimbursement constraints that eliminate the ample revenues previously received from insured patients.

As a consequence of these various social forces, some private hospitals turned desperately ill patients away from their emergency rooms, usually by transferring them to public municipal facilities. This practice of "patient dumping" led both to litigation over a private hospital's obligation to render emergency care to indigent patients and to a federal law addressing the practice (sec. A.2.b.). Because of this history and the persistence of access disparities, the following two subsections, while exploring hospital treatment duties generally, have particular importance for access to care by the indigent.

\section{a. The General Duty to Provide Care}

Wilmington General Hospital v. Manlove ${ }^{80}$ is the seminal decision that finds in the common law a duty on the part of hospitals to act reasonably in their patient selection decisions.

Manlove involved a hospital emergency room that refused to treat a severely ill infant because he was under the care of another physician who was not a member of the hospital's medical staff. As a result, the infant died. By analogy to the tort of negligent termination of gratuitous services, the court reasoned that in cases of "unmistakable emergency," a hospital that maintains an emergency room which by "established custom" has been open can properly be held responsible for refusing to treat a patient whose condition "worsens" as a consequence of time lost pursuing the unforthcoming treatment. Detrimental reliance is thus at the core of the case. Accordingly, Manlove applies only to emergency care, and even then its scope is rather limited. (Section A.2.b.1, infra).

A potentially more powerful and sweeping common law theory -- one that would cover all forms of hospital treatment -- asserts that private hospitals owe duties to the public at large on the ground that they are "quasi-public," by virtue of the importance of their services, the funding they receive from public sources, their licensure, and their tendency to enjoy monopoly status in a community. The Manlove court rejected this view, however, and it has not in fact been widely adopted, although a few courts have been receptive to it. ${ }^{81}$

\section{b. Access to Emergency Care}

Notwithstanding the absence of a general duty to rescue, in certain areas U.S. law has been slowly (perhaps even ambivalently) but perceptibly responsive to the moral challenge of taking

80174 A.2d 135 (Del.1961)

${ }^{81}$ See, e.g., Leach v. Drummond Med. Group, 192 Cal.Rptr. 650 (Cal.App.1983) (reasoning applied to the only physician group practice in town). 
action to reduce acute, visible and avoidable suffering. One of the areas in which this trend may be at work is in the legal recognition of a hospital duty to care for emergency patients irrespective of their ability to pay.

\section{i. Common Law and Statutory Rights}

Manlove was the first case to fashion a theory of relief for patients denied hospital emergency care. Its principal impact has been in securing access to emergency care by uninsured patients. In addition, many states have laws expressly requiring hospitals to treat emergency patients without regard to their ability to pay. Federal law imposes the same duty on hospitals that maintain charitable tax exemption.

These established legal protections are limited, though, by their narrow definitions of what constitutes an emergency and of the extent of treatment required in an emergency. For instance, the Manlove theory, applied in a number of states, addresses refusals to treat only in cases of "unmistakable" emergency, only where the patient's condition worsens due to the delay in finding an alternative source of care, and only where the delay is caused by reliance on an ER's open-door custom. Many of the state statutes define an emergency as a situation requiring immediate treatment in order to prevent loss of life or limb -- which can exclude a broad range of serious, albeit less extreme, medical conditions.

Two Arizona cases point the way toward a more expansive duty to provide emergency care. Eschewing Manlove's reliance-based approach, the Arizona Supreme Court has implied a sweeping duty "to provide emergency care to all persons presenting themselves for such aid" (emph. in original), ostensibly based upon the state regulatory requirement that all general hospitals maintain emergency facilities as a condition of licensure. ${ }^{82} \mathrm{~A}$ decade later the court relied on private hospital accreditation standards that prohibit discrimination based on the "source of payment," incorporated by reference into the state's hospital licensing statute, to conclude that hospitals may never transfer emergency patients on economic grounds. ${ }^{83}$

These two Arizona cases are important for two reasons. First, they are best understood as based in common law public policy -- essentially, an emergency room application of the "quasipublic status" theory discussed above -- rather than on idiosyncrasies of state regulatory law, and are thus of general rather than parochial interest. Second, they allow courts to redefine the nature of an emergency and the extent of the treatment required. Hospitals are obliged to treat any patient with a "need for immediate attention" and to provide such patients all care that is "medically indicated." The duty to treat thus encompasses far more than care necessary to prevent the patient's condition from deteriorating: "The relevant inquir[y] ... $d$ [oes] not

\footnotetext{
82 Guerrero v. Copper Queen Hospital, 537 P.2d 1329 (Ariz.1975).

83 Thompson v. Sun City Community Hospital, 688 P.2d 605 (Ariz.1984).
} 
relate to 'stabilization' and 'transferability,' but rather to the nature and duration of the emergency." 84 This broadened theory has not been adopted by other states, perhaps due to the subsequent federal enactment of, and widespread reliance on, the Emergency Medical Treatment and Active Labor Act (EMTALA) -- notwithstanding EMTALA's own arguable limitations in this connection.

\section{ii. The Emergency Medical Treatment and Active Labor Act}

The Emergency Medical Treatment and Active Labor Act of 1985 ("EMTALA"), 42 U.S.C. $1395 \mathrm{dd}$, has become the single most important legal tool governing access to emergency care, due principally to its uniform national applicability and its remedies. Hospitals that receive Medicare payment must comply with EMTALA's terms for all their patients. EMTALA creates a private right of action for damages for violation of its terms by such hospitals, though there is no comparable action against physicians. It also authorizes civil money penalties up to $\$ 50,000$ for negligent noncompliance by both hospitals and physicians.

EMTALA was enacted in the belief that state law was too weak to prevent the widespread "dumping" of indigent and uninsured patients. Its protections, however, go further: they are triggered by the refusal to properly examine or treat "any individual" who comes to a hospital emergency department seeking care, irrespective of whether the patient can pay for care or the hospital's reasons for refusing care. EMTALA requires, first, that the hospital provide for an "appropriate medical screening examination within the capability of the hospital's emergency department," to determine whether there is a medical emergency. If so, treatment must then be provided to the point of "stabilization." Specific analogous provisions also apply to women in labor.

\section{Screening}

A moment's reflection on the statutory language just quoted suggests that a diagnostic screening might be "[in]appropriate" in varying ways, and for different reasons. Uncertainty has thus arisen over just what hospital conduct the statutory phrase reaches, as well as what standard of performance it imposes. Initially, there was debate over whether EMTALA requires or assumes an improper motive for refusing treatment, based on factors such as economics, demographics, or personal characteristics. This has been criticized on the grounds that there is no statutory support for such a reading, that it is so inclusive as to be virtually without limit (and therefore meaning), and that it is nonetheless sufficiently difficult to prove that it would

\footnotetext{
${ }^{84} 688$ P.2d at 611.
} 
defeat virtually all EMTALA claims. In Roberts v. Galen of Virginia, ${ }^{85}$ the Supreme Court put this issue to rest, holding that EMTALA's stabilization requirement (and probably also its screening requirement) applies regardless of motive.

Instead of a subjective motivation test, many courts have applied a more objective test that looks to whether the patient was harmed by "disparate" or "non-uniform" treatment - some purposeful variation from the medical practices that the hospital would otherwise apply to similarly-situated persons. This approach focuses solely on whether a hospital complied with its own standard procedures, and not whether those practices are themselves reasonable. For instance, a hospital that failed to do an expensive diagnostic test on a patient with chest pains or a headache would not be liable under EMTALA for an undetected heart attack or brain aneurysm simply because other hospitals would have done the test; instead, a challenger would need to show that this particular hospital normally handled cases like this differently. Courts have adopted this "disparate treatment" analysis largely in an effort to avoid making EMTALA a federal malpractice law that would displace ordinary state-law negligence claims, a result which they believe Congress did not intend. ${ }^{86}$

\section{Treatment and Stabilization.}

If the required screening reveals an "emergency medical condition," the hospital must undertake treatment. EMTALA's definition of "emergency" is a condition reasonably likely, without "immediate" treatment, to create "serious jeopardy" to the person's health. This definition is at least as inclusive as many of those found in state common law and state statutes, and the range of conditions it covers is thus reasonably broad.

The more problematic issue is how far treatment must proceed under the statutory mandate to "stabilize" the condition. Stabilization is defined as a level of treatment likely to prevent "material deterioration" of the condition during transfer. (Transfers of unstabilized patients are permitted in limited, specified circumstances involving a written request or expected medical benefit). The facts of a pre-EMTALA case are instructive. ${ }^{87}$ An auto accident victim came to the emergency room of a private hospital with "multiple deep facial lacerations, a possible head injury, traumatic damage to the teeth and multiple bruises and contusions of the body, resulting in considerable loss of blood." The hospital merely bandaged him, took Xrays, monitored for shock and administered I.V. fluids to stabilize his blood pressure before transferring him to a Veteran's Administration hospital for further treatment. This course of

\footnotetext{
${ }^{85} 525$ U.S. 249 (1999).

${ }^{86}$ Vickers v. Nash. General Hosp., 78 F.3d 139, 142-43 (4th Cir. 1996) (reviewing cases).

87 Joyner v. Alton Ochsner Medical Foundation, 230 So.2d 913 (La.App.1970).
} 
action is probably entirely consistent with EMTALA; thus in many situations, EMTALA actually may not require more extensive care than was due under state common and statutory law. Ironically, the expansive treatment obligations in a few common law precedents (see the two Arizona cases, supra) may actually exceed the "stabilization" requirement of EMTALA. Given EMTALA's dominance of the field, however, their further application seems unlikely, even though EMTALA does not actually preempt such common law claims.

\section{iii. "Preventive" Dumping.}

EMTALA requires screening and stabilization of anyone who "comes to" an emergency department. Under this language courts have rejected EMTALA claims by patients who do not, literally, show up at the hospital. By regulation, the Secretary of Health and Human Services has confirmed that "comes to" requires physical presence on hospital property; however, a hospital's own ambulance is deemed hospital property, and, arguably, non-hospital ambulances cannot be re-routed except for reasons of lack of hospital capacity or staff.

EMTALA has not been without controversy. Some have criticized it for responding to a problem that was never as widespread as claimed or that no longer exists, and for imposing an awkward and poorly drafted solution. Others believe that EMTALA has been effective; still others that patient dumping persists at unacceptable levels, notwithstanding EMTALA. Under any view, however, EMTALA has become central to the law of access to emergency medical care, and there is little reason to believe its role will decline.

\section{Doctors within Health Care Organizations}

How can hospitals, dependent on doctors to deliver care, comply with their institutional duty to treat (under the various legal theories explored above) if Hurley leaves physicians free to refuse patients? One solution is regulatory: since EMTALA was enacted, physicians are no longer completely free to refuse emergency patients with impunity, because they may face civil fines for negligent noncompliance with EMTALA's terms. A second solution (pre-EMTALA) is contractual. Hospitals may require as a condition of medical staff membership that physicians assist in treating emergency and indigent patients. If physicians accept this condition by joining the medical staff or working in the emergency room, then this contractual obligation may extend to the patient as a third-party beneficiary. ${ }^{88}$

A similar solution applies to managed care, where a health plan may contractually bind participating physicians to see individuals it has a contractual duty to treat. In Hand v. Tavera, ${ }^{89}$

\footnotetext{
${ }^{88}$ Hiser v. Randolph, 617 P.2d 774 (Ariz.1980).

${ }^{89} 864$ S.W.2d 678 (Tex. App. 1993). 
the court relied on the applicable contracts (characteristic of health plans) to find a treatment relationship with the plan's on-call physician. The physician refused to authorize the patient's admission to the plan's hospital based on the symptoms and history conveyed by a telephone consult from the ER. As a consequence, the patient had a stroke at home. The court reasoned that the enrollee paid premiums to the plan to purchase medical care in advance of need; the plan arranged to meet its obligation to provide care by paying physicians; those physicians, in return, agreed to treat the plan's members. The identity of the physician who happened to be on call for emergency admissions was immaterial: the plan brought the patient and physician together "just as surely as though they had met directly and entered the physician-patient relationship." 90

\section{Wrongful Denials: Antidiscrimination Law and Refusal to Treat}

As discussed thus far, physicians (and, to a considerably lesser extent, hospitals) enjoy substantial legal discretion to refuse patients for "good" reasons, "bad" reasons, or no stated reason at all. In a limited number of areas, which are the subject of this section, federal law specifically disapproves certain bases for treatment refusals. In addition, states often have counterpart regulatory laws, generally applicable to "public accommodations" (which covers hospitals but often not medical offices). Private accreditation standards also prohibit discriminatory practices by hospitals on the basis of race and other characteristics, including source of payment, and the federal charitable tax exemption for hospitals carries with it certain obligations to provide care on a nondiscriminatory basis to paying patients.

\section{Title VI: Race, Ethnicity, and Gender.}

Title VI of the federal civil rights law, enacted in 1964, prohibits any "program or activity receiving federal financial assistance" from discriminating against, excluding, or denying benefits to individuals on the grounds of race, color, or national origin. ${ }^{91}$ Thus, overt discrimination by hospitals participating in the federal Medicare or Medicaid programs (which were enacted in 1965) or receiving other financial support is barred. Despite Title VI, subtler forms of racial (as well as gender) discrimination by health care providers doubtless persist. For instance, Title VI has been invoked in a few cases challenging decisions to relocate or to close hospitals serving predominantly minority populations.

Until 2010, however, there was no clear prohibition of discrimination that applied to physicians. That is because, prior to the Affordable Care Act, courts and regulators interpreted Title VI as not applying to physicians at all. (Even though physicians receive federal funds

\footnotetext{
90864 S.W. 2 d at 679.

${ }^{91} 42$ U.S.C. 2000 d.
} 
through Medicare and Medicaid, courts and regulators interpreted those programs in a strained way that avoided triggering Title VI.) The ACA changed this legal landscape by broadening the definition of federally funded activities to include funding of physician services, and also by extending the prohibition to discrimination based on gender.

\section{Disability Discrimination}

Two closely related laws, both of which apply to a wide range of activities beyond health care, have become important in this field: Section 504 of the Rehabilitation Act of 1973 (29 U.S.C. 794), and the Americans with Disabilities Act of 1990 (42 USC 12101). HIV/AIDS first drew attention to the application of disability law to health care, and HIV cases continue to arise and receive coverage, but the application of disability discrimination law to health care is considerably broader.

The most obvious difference between the two laws is the reach of their regulation. Section 504 applies to federally funded "programs and activities" (which includes hospitals that receive Medicare reimbursement, but probably not doctors). The ADA, by contrast, reaches various entities irrespective of whether they receive federal financial assistance, including state and local governments (Title II) and public accommodations (Title III). Of greatest importance here, the latter include the "professional office of a health care provider, hospital, or other service establishment," so doctors' offices are covered. While there is more case law developed under sec. 504 because it has been in effect for so much longer, the greater reach of the ADA suggests that it will ultimately supersede section 504 in importance.

\section{a. Protected Class.}

The first question in most disability discrimination cases is whether the individual falls within the protected class. Section 504 protects a "handicapped individual," defined as someone with a "physical or mental impairment which substantially limits one or more of such person's major life activities," or someone with either a "record of," or who is "regarded as having," such an impairment. The ADA's definition of "disability," except for the choice of the operative word, is almost verbatim. ${ }^{92}$

These terms are quite broad, reflecting Congress' intent to protect people against discrimination arising not only from prejudice but also from fear and myth. ${ }^{93}$ Echoing those policies, the Supreme Court held that non-symptomatic HIV infection constitutes a disability under the ADA. In Bragdon v. Abbott, ${ }^{94}$ an HIV-positive patient alleged that her dentist violated

\footnotetext{
9242 U.S.C. $12102(2)$.

93 School Bd. of Nassau County v. Arline, 480 U.S. 273, 279, 284 (1987).

94524 U.S. 624 (1998)
} 
the ADA when he refused to fill a cavity for her in his office (offering, instead, to do so at a hospital, though there was no evidence the hospital would be safer or even that he had privileges to practice there). The Court held that non-symptomatic HIV infection constitutes (in the statutory terms) a "physical impairment" from the moment of infection onward, and that, by interfering with the plaintiff's reproductive capacity, the infection "affected a major life activity" because of the centrality to life of reproduction and sexual relations. The open-ended nature of this "major life activity" category is suggested by the Court's intimation that other plaintiffs might persuasively assert that HIV impacts other life activities, as well. Finally, the Court concluded that HIV infection was a "substantial limit" on the plaintiff's reproductive activity, noting that her status would impose significant risks of infection on male sexual partners (20-25\%), and on any child during gestation and childbirth (8-25\%). The Court emphasized that this third requirement is met "even if the difficulties [generated by the disability for the life activity in question] are not insurmountable."

\section{b. Core Provisions}

Finding a handicap or disability is only the first inquiry. Section 504 prohibits regulated programs or activities from excluding, denying benefits to, or discriminating against any "otherwise qualified handicapped individual...solely by reason of his handicap." 29 U.S.C. 794. "Otherwise qualified" means able to meet program requirements "in spite of" the handicap, as established through an individualized, factually-specific inquiry. So, for example, a quadriplegic would not be otherwise qualified to work on construction sites but would be otherwise qualified to work at desk jobs. Even where people cannot initially meet all program or activity requirements, they may nonetheless be "otherwise qualified" if the sponsor of the program or activity can make "reasonable accommodation"-- i.e., take steps, short of incurring "undue financial and administrative burdens" or making "a fundamental alteration in the nature of the program" (Arline, supra), that would enable the person to meet the requirements, in which case the sponsor must do so. The ADA rules, though not identical, are similar.

A key difficulty in disability law is determining whether a person is "otherwise qualified" for the benefit or service. Classical applications of this standard arise in cases involving access to education and employment, in which the analysis has two salient characteristics: (1) it impliedly assumes that the benefit or service is generally available to a qualified class of people, under eligibility requirements established by its sponsor; and (2) because the disability is not the reason for which the person seeks the benefit or service, it is coherent to ask whether the person can meet the eligibility terms notwithstanding (or "in spite of") the disability, with any needed reasonable accommodation.

In health care, this analysis applies logically enough where an individual is seeking access to care for a problem that is unrelated to his disability, as where a physician who is treating a 
patient for an ear infection refuses to perform medically indicated surgery after learning that the patient is HIV positive. The benefit (ear surgery) is generally available on certain terms to those who need it; and, since the patient is seeking care for a condition other than the disability (HIV status), it is coherent to ask whether, with reasonable accommodation (here, relating to the patient's infectiousness and immunocompromise), the patient qualifies for the benefit "in spite of" that disability.

But in cases in which it is precisely the disability that gives rise to the need for access to health care, this is not a very coherent approach to "otherwise qualified." A major case in this regard arose when a hospital wanted to deny artificial ventilation to an infant with anencephaly whose respiratory distress was a result of the anencephaly. With some struggle, a few courts have found a meaningful approach in these cases. They preclude a health care provider from using disability alone as the basis for withholding medical benefits. A person is "otherwise qualified" for a particular medical benefit if "there is no factor apart from the mere existence of disability that renders the participant unqualified for the benefit." 95 To withhold care, the provider would need to have a "bona fide medical reason" for the denial. This would allow a physician to refuse care based on the claim that the physicians felt under-qualified to treat the patient's particular condition. Or if the patient's condition would preclude a successful outcome from treatment, as with a kidney transplant in a patient with lung cancer, care could be denied on account of the condition.

\section{Modifying the Terms of the Treatment Relationship}

Although the formation of the treatment relationship is essentially contractual in nature, once established, tort and fiduciary law generally govern the parties' conduct and their mutual obligations, through doctrines such as medical malpractice and informed consent. This section explores the extent to which patients and physicians are free to modify those rules and define the terms of their relationship in accordance with their own preferences.

Courts have generally refused to enforce agreements with patients by which health care providers try to waive their liability for negligence. The leading case is Tunkl v. Regents of the University of California ${ }^{96}$ in which the California Supreme Court concluded that a hospital's exculpatory agreement with a patient, signed at admission, bore all the indicia of an unconscionable adhesion contract.

Tunkl and similar cases do not, by their terms, preclude liability waivers that fall short of full exculpation, and in fact courts are likely to enforce releases from liability where the care

95 Woolfolk v. Duncan, 872 F. Supp. 1381, 1389-90 (E.D. Pa. 1995) (seeking care for, and alleging discrimination based on, HIV status).

96383 P.2d 441 (Cal. 1963). 
provided departs from standard medical practice for good reason, as when a patient leaves the hospital early against medical advice, or refuses recommended medical treatment. In this connection, consider Shorter $v$. Drury, ${ }^{97}$ holding that a document signed by a Jehovah's Witness surgical patient, releasing providers from responsibility for consequences "due to my refusal to permit the use of blood," constituted an enforceable assumption of the risk of an otherwiseavoidable death by the patient, rather than an unenforceable exculpation of negligence for the physician.

Courts have also responded favorably to agreements changing the forum or mechanism of dispute resolution. For example, HMOs may require their members to arbitrate rather than litigate medical negligence claims, at least where this is agreed to through bargaining by a powerful representative (a large employer) and there is a choice of alternative plans. ${ }^{98}$ On the other hand, "point of treatment" arbitration agreements, presented for signature upon hospital admission or at the doctor's office, are less likely to receive judicial approval because of concerns about their fairness, though these decisions too are not uniform.

Agreements to alter the prevailing standard of care, rather than to waive it entirely as in Tunkl, are more difficult. If notice is adequate and there is some choice, should HMOs (for example) be allowed to contractually bind enrollees to accept a lower-than-normal standard of care (e.g., anything above "gross negligence") by plan providers, as a cost-containment mechanism that would benefit enrollees by reducing premiums? The law on such questions is not well-developed, but is likely to be a focal point of controversy as medical standards are increasingly subsumed within managed care contractual arrangements. ${ }^{99}$

\section{E. Terminating the Treatment Relationship}

Professional duties arise upon the formation of a treatment relationship and continue until it is properly terminated. Patient "abandonment" is the term applied to an improper termination of treatment that is intentional, in contrast with termination that is due to a mistake in medical judgment. The latter is a matter for ordinary malpractice law, but this distinction is frequently confused.

Where a treatment relationship exists, the law of abandonment requires that the physician (or hospital) provide all necessary care unless the relationship is terminated (1) by the patient or (2) by the provider, after giving the patient proper notice and an opportunity to secure an

97695 P.2d 116 (Wash. 1985).

98 Madden v. Kaiser Foundation Hospital, 552 P.2d 1178 (Cal. 1976).

${ }^{99}$ For competing arguments, see Clark Havighurst, Health Care Choices: Private Contracts as Instruments of Health Reform (1996) (endorsing such a contractarian approach); Maxwell Mehlman, Fiduciary Contracting: Limitations on Bargaining Between Patients and Health Care Providers, 51 U. Pitt. L. Rev. 365 (1990) (criticizing it). 
alternate source of care. Abandonment law is thus much more forgiving than is usually recognized. The only explicit restraint on a doctor's (or hospital's) freedom to abandon a patient is the procedural one of notice. As classically conceived, there is no real substantive content to abandonment law because the law does not scrutinize the reasons for abandonment: so far as abandonment law is concerned, doctors may, with proper notice, stop treatment because they want to retire, or go on vacation, or simply because they dislike the patient.

To ensure that there is no question about the adequacy of notice to the patient and opportunity to obtain substitute care, prudent physicians as a practice usually take affirmative steps themselves to arrange for substitute care. Vacationing doctors will usually have associates cover their cases and retiring doctors will ordinarily tell patients that a designated physician has agreed to take their cases. Prudent hospitals, likewise, will never simply discharge an ill patient, even after ample notice; instead, they will locate an alternative facility to which a patient can be transferred.

These pragmatic accommodations have created a degree of uncertainty in abandonment law. Because this body of law is based on an implied contractual undertaking and on notions of fiduciary responsibility, its precise limits are not firmly set. Consequently, the case law in different states offers conflicting indications of whether simple notice of treatment termination is sufficient, or whether instead the law requires health care providers to arrange for a substitute source of care.

This point becomes a critical issue in the modern context where doctors and hospitals face increasingly severe constraints in health care reimbursement. A provider might seek to terminate care because the patient's insurance runs out or won't cover the treatment. If patients are given "notice," and perhaps appeal rights, will this suffice under the usual procedural requirements of abandonment doctrine -- or might a creative and sympathetic plaintiff persuade a court to read a substantive element into the doctrine, and prohibit the termination of treatment based on inability to pay?

Three cases shed conflicting but ambiguous light on the legality of "economic abandonment." In Ricks v. Budge, ${ }^{100}$ the court allowed the plaintiff to maintain an action alleging the following facts: After ordering Mr. Ricks to the hospital for a seriously infected hand, Dr. Budge refused treatment and walked out because Mr. Ricks would not immediately catch up on his past due accounts. This decision is frequently cited by commentators for the proposition that it is illegal to abandon a patient who cannot pay. However, these facts do not support a general prohibition of economic abandonment. Instead, the holding is perfectly consistent with purely "procedural" abandonment law, which only requires the doctor "to give

${ }^{100} 64$ P.2d 208 (Utah 1937). 
the patient sufficient notice so the patient can procure other medical attention if he desires," id., and prohibits patient abandonment only at a critical stage in the course of treatment.

Additional support for this view is suggested in a leading abandonment decision, Payton v. Weaver. $^{101}$ There, the court allowed a physician to stop treating an uncooperative patient despite the unavailability of any substitute care. This case concerned a renal dialysis patient who "frequently appear[ed] for treatment late or at unscheduled times in a drugged or alcoholic condition, used profane and vulgar language, and on occasion engaged in disruptive behavior, such as ... cursing staff members with obscenities." Although Dr. Weaver's attempts to find alternative treatment centers were unsuccessful, the court held that he "gave sufficient notice of [his intent to cease treatment] and discharged all his obligations." It is difficult to determine, though, whether Payton $v$. Weaver invokes a purely procedural abandonment rule because its compelling facts might also provide substantive justification for the decision to discontinue treatment.

Finally, in Muse v. Charter Hosp. Winston-Salem, ${ }^{102}$ the court ruled that a psychiatric hospital illegally interfered with the physician's medical judgment when it encouraged the discharge of an adolescent patient whose insurance ran out, which led to the patient's suicide three weeks later. Although the opinion never mentions the abandonment doctrine, it is based on the hospital's alleged "policy or practice" of discharging patients when their insurance runs out. Even so, the decision is subject to the same uncertainty as Ricks and Payton: we don't know whether the hospital is liable because the discharge policy is per se wrong or because of the procedure it followed failed to sufficiently notify the parents of their son's fragile condition so they would be sure to find alternative care. Even with such notice, however, a patient who is discharged for financial reasons might be unable to find a suitable alternative source of care, making it difficult for the initial provider to terminate care in a legally safe manner.

\section{CONCLUSION}

What is evident from the above discussion of access to health care in the U.S. is that there is no singular, coherent set of guidelines or polices that determine who has access to what and when. The lack of constitutional rights and of any centralized system of financing or regulating access has created great legal and policy complexity. Although the basic moral questions that inform policy and legal development are the same in the U.S. as in Europe, the U.S. deals with these questions on a case-by-case basis and in opaque ways that often simply avoid answering them altogether. The result is that the most defining characteristic of access to medical care in the U.S. is its inequity.

\footnotetext{
101182 Cal.Rptr. 225 (1982).

102452 S.E.2d 589 (N.C. App. 1995), aff'd mem., 464 S.E.2d 44 (N.C. 1995).
} 